\title{
Type 1 cryoglobulinaemia presenting as digital ischaemia in chronic lymphocytic leukaemia
}

\author{
Joel McCay, Joseph Scott
}

Haematology, Royal Free London NHS Foundation Trust, London, UK

Correspondence to Dr Joel McCay, joelmccay@hotmail.co.uk

Accepted 17 April 2018

\section{DESCRIPTION}

A 60-year-old Caucasian man with untreated chronic lymphocytic leukaemia presented with a 3-month history of recurrent arthralgia and joint swelling, predominantly affecting the knee, wrist and DIP joints. He subsequently developed painful, dusky fingers and was referred to the haematology department at the Royal Free Hospital for investigation (figure 1).

On admission, a full blood count revealed: $\mathrm{Hb}$ $92 \mathrm{~g} / \mathrm{L}$, white cell count $86.7 \times 10^{9} / \mathrm{L}$ with a lymphocyte differential of $77.2 \times 10^{9} / \mathrm{L}$ and platelets 332 . Renal, liver and bone profiles within normal ranges. Cryoglobulins were detected, and subsequent immunofixation showed the presence of a type 1, monoclonal IgM lambda cryoglobulin.

The patient was managed with a continuous iloprost infusion, high dose corticosteroid therapy, plasmapharesis, rituximab and subsequently a dose of cyclophosphamide. On discharge, he was referred to University College Hospital for long-term management of CLL. He was referred to plastic surgery for amputation of affected digits (figure 2).

Type 1 cryoglobulinaemia is a rare disorder characterised by monoclonal production of immunoglobulins that precipitate at cold temperatures and can cause microvascular damage. The damage in this case led to end tissue damage and significant changes to the patient's quality of life. ${ }^{1}$ It can manifest in a number of ways, and it is therefore

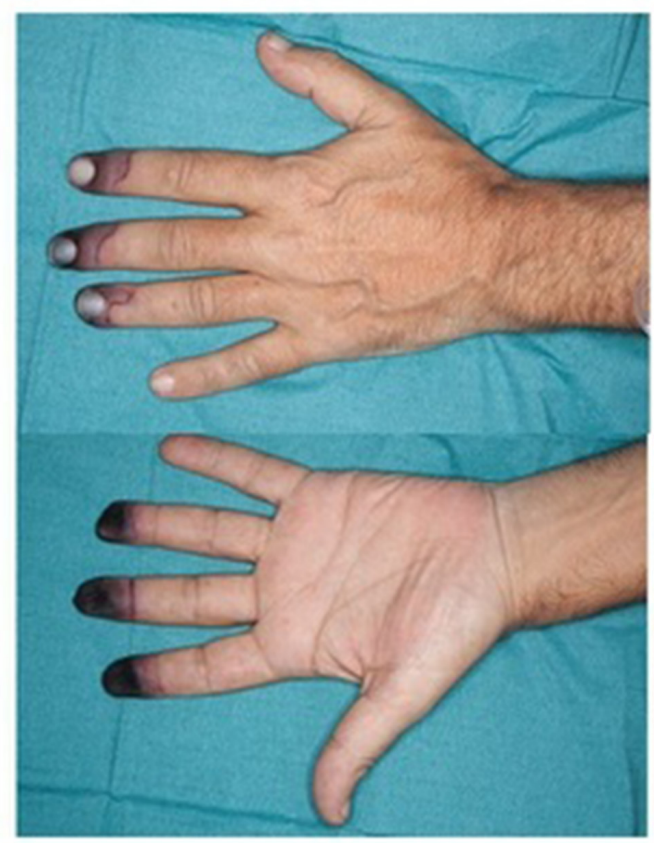

Figure 1 Before treatment.

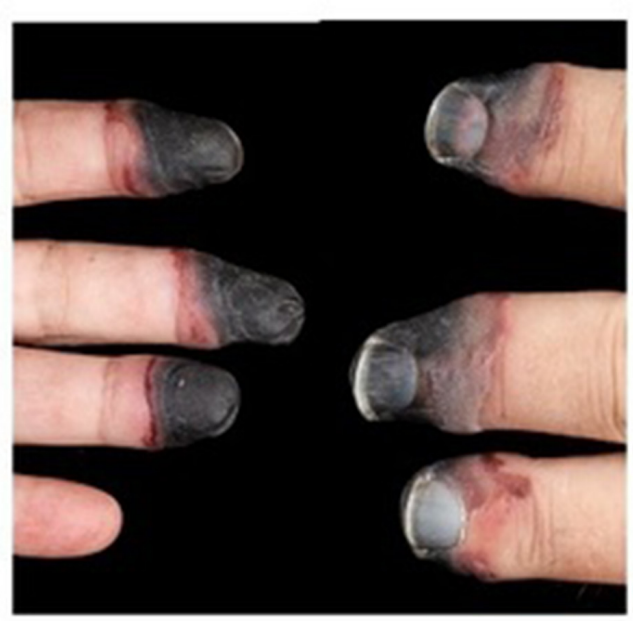

Figure 2 After treatment, showing halting of necrosis. important to appreciate the accompanying underlying disorders that can drive it.

\section{Learning points}

- Type 1 cryoglobulinaemia is a rare disorder characterised by monoclonal production of immunoglobulins that precipitate at cold temperatures and can cause microvascular damage.

- It makes up 10\%-15\% of cryoglobulinaemias and is typically associated with lymphoproliferative disorders.

- Response to treatment is often monitored using cryocrit percentage or paraprotein quantification.

Contributors JM: senior house officer. JS: foundation year 1 doctor. All research undertaken at The Royal Free Hospital. Both authors contributed equally to all aspects of planning, writing and designing the attached report.

Funding The authors have not declared a specific grant for this research from any funding agency in the public, commercial or not-for-profit sectors.

Competing interests None declared.

Patient consent Obtained.

Provenance and peer review Not commissioned; externally peer reviewed.

(C) BMJ Publishing Group Ltd (unless otherwise stated in the text of the article) 2018. All rights reserved. No commercial use is permitted unless otherwise expressly granted.

\section{REFERENCE}

1 Sidana S, Rajkumar SV, Dispenzieri A, et al. Clinical presentation and outcomes of patients with type 1 monoclonal cryoglobulinemia. Am J Hematol 2017;92:668-73. 
Copyright 2018 BMJ Publishing Group. All rights reserved. For permission to reuse any of this content visit http://group.bmj.com/group/rights-licensing/permissions.

BMJ Case Report Fellows may re-use this article for personal use and teaching without any further permission.

Become a Fellow of BMJ Case Reports today and you can:

- Submit as many cases as you like

- Enjoy fast sympathetic peer review and rapid publication of accepted articles

Access all the published articles

- Re-use any of the published material for personal use and teaching without further permission

For information on Institutional Fellowships contact consortiasales@bmjgroup.com

Visit casereports.bmj.com for more articles like this and to become a Fellow 